\title{
An exocytotic mutant of Paramecium caudatum: membrane fusion without secretory contents release
}

\author{
Norbert Klauke', Roland Kissmehl', Helmut Plattner', \\ Nobuyuki Haga' ${ }^{2}$, Tsuyoshi Watanabe ${ }^{3}$ \\ 'Department of Biology, University of Konstanz, Konstanz, Germany \\ ${ }^{2}$ Department of Biotechnology, Senshu University, Ishinomaki, Miyagi, Japan \\ ${ }^{3}$ Biological Institute, Faculty of Science, Tohoku University, Sendai, Japan
}

\begin{abstract}
Summary This is a detailed characterization of a secretory mutant incapable of releasing secretory contents despite normal exocytotic membrane fusion performance. Trichocyst non-discharge strain tnd1 of Paramecium caudatum and its wildtype (wt) both show a transient cortical $\left[\mathrm{Ca}^{2+}\right]_{i}$ increase and exocytotic membrane fusion in response to the polyamine secretagogue, aminoethyldextran (AED), or to caffeine. tnd1 cells frequently display spontaneous $\mathrm{Ca}^{2+}$ signals parallelled by spontaneous exocytotic membrane fusion. This remains undetected, unless the trichocyst matrix is shown to be freely accessible to the inert, non-membrane permeable fluorochrome, $F_{2} F I T C$, from the outside. In these tnd 1 cells, spontaneous and AED- or caffeine-induced membrane fusion, always without contents expulsion by decondensation (i.e. several-fold stretching), is ascertained by electron microscopy. Exocytotic openings, with condensed trichocysts retained, may persist for hours without impairing cells. Trichocyst decondensation normally requires micromolar $\left[\mathrm{Ca}^{2+}\right]_{\mathrm{e}}$, but an increase to $10 \mathrm{mM}$ has no effect on tnd1 trichocyst expansion in vivo or in vitro (when isolated and exposed to ionophore A23187 $+\mathrm{Ca}^{2+}$ ). Paracrystalline packing of the major secretory components (trichynins) does occur, despite incomplete proteolytic precursor processing (according to SDS-PAGE). However, ${ }^{45} \mathrm{Ca}^{2+}$-binding by secretory components is considerably reduced - the likely cause of the non-discharge phenotype. Our findings imply significant untriggered membrane fusion in a system normally following the triggered pathway and clear separation of exocytotic membrane fusion from any later $\mathrm{Ca}^{2+}$-dependent steps of the secretory cycle.
\end{abstract}

\section{INTRODUCTION}

Exocytosis normally comprises membrane fusion and release of contents, followed by endocytotic membrane fission and rapid detachment of empty 'ghost' membranes, as ascertained in a variety of cell types [1-10]. This also holds for Paramecium cells [11-13]. Using the polyamine secretagogue, aminoethyldextran (AED), all steps could be

Received 1 December 1997

Revised 9 March 1998

Accepted 13 March 1998

Correspondence to: Dr Helmut Plattner, Department of Biology, University of Konstanz, PO Box 5560, D-78434 Konstanz, Germany

Fax: +497531882245 synchronized to within the sub-second range in $P$. tetraurelia cells [12-14] for which we also showed caffeine to act as an agonist [15]. Both AED and caffeine have been used in the present study.

It is well established that exocytotic membrane fusion requires a local increase in intracellular $\mathrm{Ca}^{2+}$ concentration, $\left[\mathrm{Ca}^{2+}\right]_{\mathrm{i}}$, in Paramecium [15-18], just as in any other secretory system $[2,10]$. Once an exocytotic opening has been formed, secretory contents 'see' the extracellular medium which causes dispersal of secretory components (see Discussion). In fact, contents' release has been shown for the first time in Paramecium to be an independent step of the secretory cycle [19]. In this case, transformation of the 'condensed to the 'decondensed' state is vigorous, taking only $<1 \mathrm{~ms}$ [13] and causing several-fold elongation of pear-shaped trichocyst contents to rod-like structures 
- a process easily recognized in the light microscope (LM), [20,21]. In Paramecium, this step is triggered by access of extracellular $\mathrm{Ca}^{2+}, \mathrm{Ca}^{2+}{ }_{e^{\prime}}$ in the micromolar range [19,21-24]. Conversely, $x$-ray microanalysis was unable to document the presence of $\mathrm{Ca}^{2+}$ in resting trichocysts in situ [25-27], i.e. before decondensation.

Mechanisms governing condensation of secretory contents and their decondensation during release may be quite different in different systems, depending on the type of contents stored. In contrast to trichocysts, most secretory organelles contain $\mathrm{Ca}^{2+}$ in millimolar concentrations, which keeps secretory proteins in a condensed state [28-32]. Also, most secretory organelles are acidic compartments [33] which additionally might facilitate maintainance of predominantly acidic secretory proteins in a condensed state. In this regard, trichocysts are also different since they are not remarkably acidic compartments $[34,35]$, and their main content proteins ('trichynins') have $\mathrm{pI}$ values of $\leq 6.1$ [36-38].

In $P$. tetraurelia, elucidation of secretory mechanisms has been facilitated by the availability of many mutants, ranging from trichocyst-free strain tl [39] to nondischarge (nd) strains which cannot perform exocytotic membrane fusion though their trichocysts are docked at the cell membrane [40-44], just as in wildtype (wt) cells [11]. Some nd-mutants, tnd1 and tnd2, have also been described in $P$. caudatum $[45,46]$.

The $P$. caudatum strain tnd 1 has now been analysed in more depth, particularly with regard to $\mathrm{Ca}^{2+}$ signalling (by Ca-fluorochromes), membrane fusion (by exogenous fluorochrome and by electron microscopy), and $\mathrm{Ca}^{2+}$ binding to secretory contents (by ${ }^{45} \mathrm{Ca}^{2+}$ overlays), to explain the non-discharge phenotype. Surprisingly, all but the last step were found normal. Therefore, tnd 1 cells represent the first secretory system blocked selectively at the level of contents' discharge. This, of course, also impedes performance of any of the subsequent steps.

\section{MATERIALS AND METHODS}

\section{Cells}

$P$. caudatum cells, wildtype (wt) strain or strain tnd 1 and tnd2 $[45,46]$, were cultivated monoxenically, with Enterobacter aerogenes added, at $25^{\circ} \mathrm{C}$.

\section{$\left[\mathrm{Ca}^{2+}\right]_{1}$ analyses}

These were performed as indicated previously $[17,18]$. Briefly, cells were microinjected with $\mathrm{Ca}^{2+}$-sensitive fluorochromes from Molecular Probes (Eugene, OR, USA), i.e. with $100 \mu \mathrm{M}$ Fluo-3 (final concentration in cells) for $\mathrm{f} / \mathrm{f}_{\mathrm{o}}$ imaging, or with $50 \mu \mathrm{M}$ Fura-Red to determine absolute $\left[\mathrm{Ca}^{2+}\right]_{\mathfrak{i}}$ values at rest. A confocal laser scanning microscope (CLSM) from Noran (Bruchsal, Germany), operated with a fast opto-acoustic beam deflection system, was used for fast $\mathrm{f} / \mathrm{f}_{\mathrm{o}}$ analysis whose feasibility was shown previously [17]. For double wavelength recordings of Fura-Red signals, see [18]. Some cells were observed without stimulation, others were stimulated, 2 min after fluorochrome injection, by a local flush of the secretagogue, AED $(0.01$ or $0.1 \%)$, or of caffeine $(40 \mathrm{mM})$. Occasionally secretagogues were supplemented with an excess of $\mathrm{Ca}^{2+}$, up to $10 \mathrm{mM}$, in the medium (to monitor decondensation capability) or with $\mathrm{F}_{2}$ FITC (Molecular Probes), $10 \mu \mathrm{M}$ (to visualize free access of trichocyst contents after membrane fusion without secretory contents discharge).

\section{Electron microscopy}

For freeze-fracturing and platinum/carbon replication, cells were frozen in melting propane, either without (for controls) or with previous fixation $(2.5 \% \mathrm{v} / \mathrm{v}$ glutaraldehyde in $0.1 \mathrm{M}$ PIPES buffer $\mathrm{pH} 7.0$ at $0^{\circ} \mathrm{C}$ for $30 \mathrm{~min}$ ), followed by impregnation with glycerol (up to $30 \% \mathrm{v} / \mathrm{v}$ ). Both methods gave similar results.

For ultrathin sectioning, cells were fixed as indicated above, followed by $1 \% \mathrm{OsO}_{4}$ in PIPES buffer $\mathrm{pH} 7.0$ at room temperature for $1 \mathrm{~h}$. This was followed by dehydration in acetone and embedding in Spurr's resin.

\section{Isolated trichocyst fractions}

Trichocysts were isolated with intact membranes in a medium of $5 \mathrm{mM}$ PIPES buffer $\mathrm{pH} 7.0$, supplemented with $5 \mathrm{mM} \mathrm{MgCl}_{2}$ and $0.15 \mathrm{M} \mathrm{NaCl}$, according to [23]. Samples were checked for purity under phase contrast and used for ionophore experiments or for gel electrophoresis.

\section{Ionophore experiments}

$t^{2}$

Trichocyts isolated in the medium indicated above were incubated at room temperature for $10 \mathrm{~min}$ with $100 \mu \mathrm{M}$ ionophore A23187 (Calbiochem, Bad Soden, Germany) in $2 \% \mathrm{v} / \mathrm{v}$ DMSO. Then up to $50 \mathrm{mM} \mathrm{CaCl}{ }_{2}$ was added during observation in a phase contrast microscope.

\section{Gel electrophoresis}

Isolated trichocysts were heated to $100^{\circ} \mathrm{C}$ for $3 \mathrm{~min}$ and processed, without or with $0.5 \%$ dithiothreitol (DTT) added, after treatment for $30 \mathrm{~min}$ with $0.2 \% \mathrm{v} / \mathrm{v}$ iodoacetamide, on 10-20\% gels. For sodium dodecylsulfate (SDS) polyacrylamide gel-electrophoresis (PAGE) we included low molecular weight (LMW) markers from Pharmacia (Uppsala, Sweden) as well as myosin. Further 

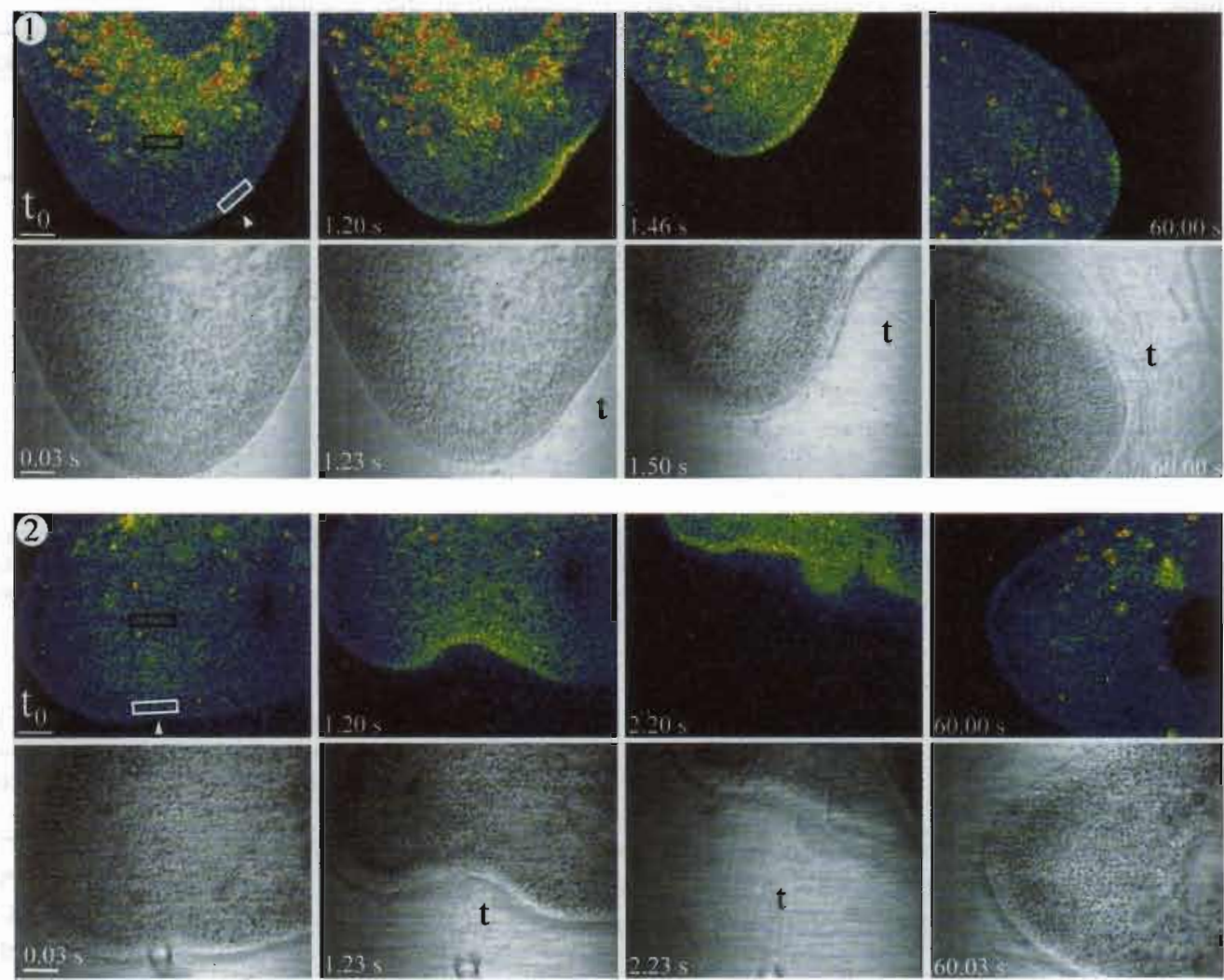

Figs $1-4$ Fluo $-3(100 \mu \mathrm{M}$ in cell, 1 min dissipation time) injected wt (Figs $1 \& 2$ ) or tnd 1 cells (Figs $3 \& 4$ ),
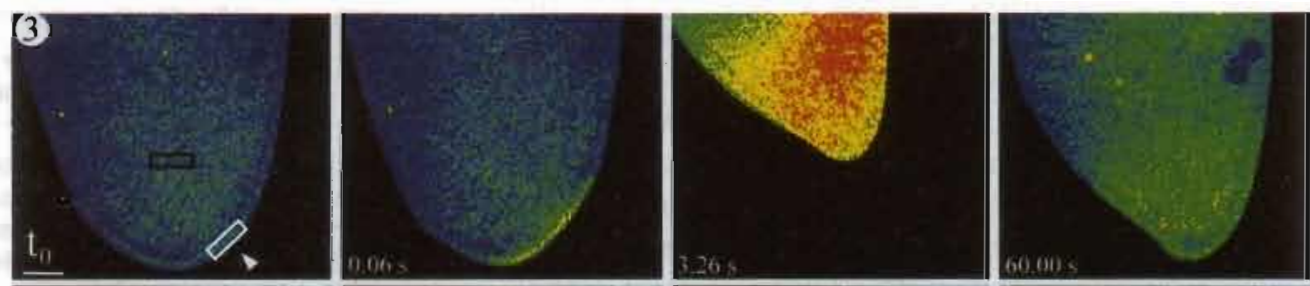

(Figs 1

\& 3) or to $40 \mathrm{mM}$ caffeine

(Figs 2 \& 4) applied at

arrowhead (with application

capillary visible in Figs $2 \& 3$ )

Cells show $\left[\mathrm{Ca}^{2+}\right]_{\mathrm{i}}$ transients

as false colour image

evaluation from CLSM (top

rows) and transmitted light

images (differential

interference contrast, bottom

rows), but only wt cells

release trichocysts $(\mathrm{t}) .\left[\mathrm{Ca}^{2+}\right]_{e}$

$=50 \mu \mathrm{M}$. Sequestered

fluorochrome causes false red dot signals which do not

change during analysis. Note

deformation and distortion of

cells during discharge of

some trichocysts (t), while in

wt cells most and in tnd 1 cells

all trichocysts (visible as $\sim 10$

um long rods in the cortex)

remain in the cells. Framed

areas are analyzed in Figure 5.

Bars $=10 \mu \mathrm{m}$.
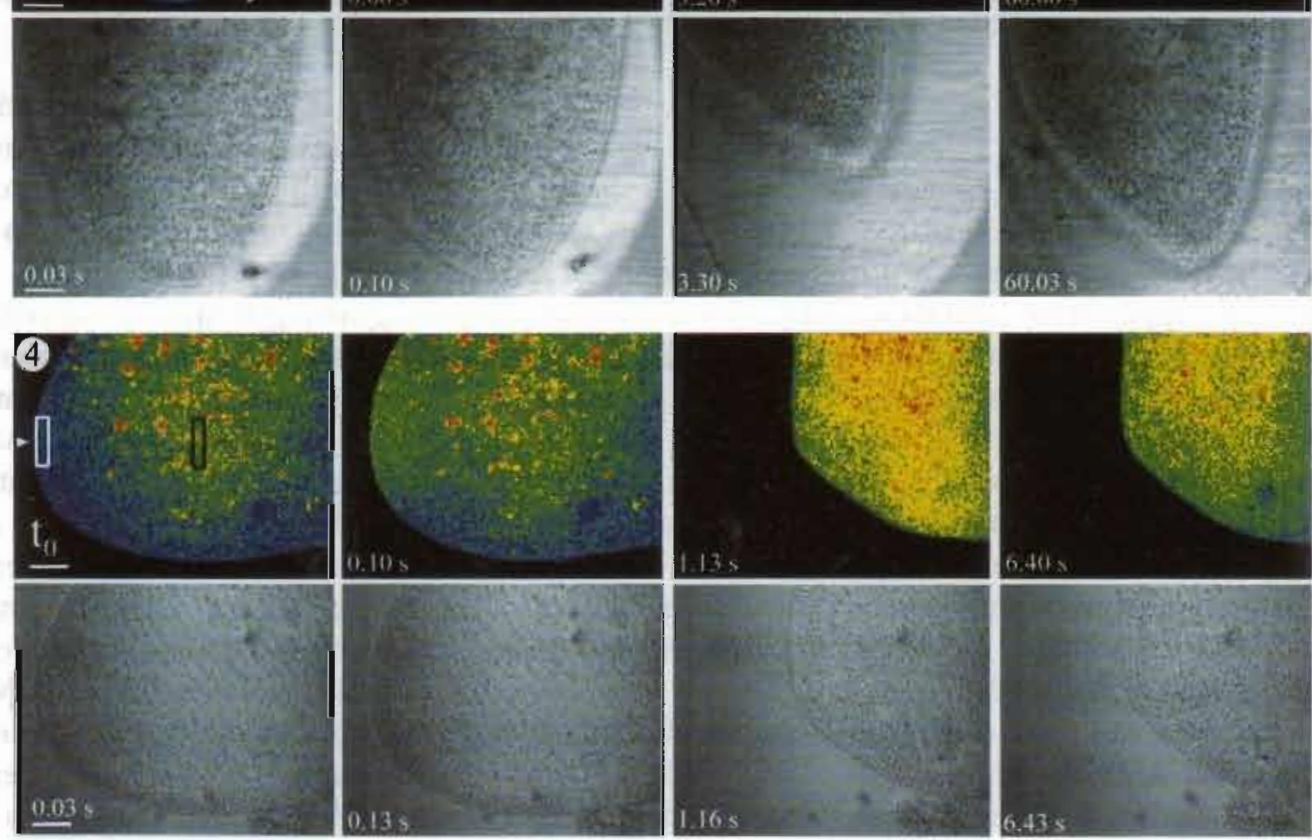
Table 1 Exocytosis and $\left[\mathrm{Ca}^{2+}\right]_{i}$ transients achieved in $P$. caudatum $w t$, tnd 1 and tnd2 cells ${ }^{a}$

\begin{tabular}{|c|c|c|c|c|c|}
\hline \multirow{3}{*}{$\begin{array}{l}\text { Strain } \\
(n)^{\mathrm{b}}\end{array}$} & \multirow[t]{3}{*}{ Trigger } & \multirow{2}{*}{\multicolumn{2}{|c|}{$\begin{array}{c}\text { Maximal }\left[\mathrm{Ca}^{2+}\right]_{i} \\
\left(\text { rise of } f / f_{o}\right)^{c}\end{array}$}} & \multicolumn{2}{|c|}{ Exocytotic response } \\
\hline & & & & \multirow{2}{*}{$\begin{array}{c}\text { Discharge } \\
\mathrm{F}_{2} \mathrm{FITC}^{\mathrm{d}}\end{array}$} & \multirow{2}{*}{$\begin{array}{l}\text { Membrane } \\
\text { fusion }^{d}\end{array}$} \\
\hline & & Cortical & Central & & \\
\hline wt (6) & $0.1 \%$ AED & $2.9 \pm 0.2$ & $2.3 \pm 0.9$ & $+/+$ & + \\
\hline wt (4) & $0.01 \%$ AED & 0.0 & 0.0 & $-1-$ & - \\
\hline tnd1 (4) & $0.1 \%$ AED & $2.6 \pm 0.8$ & $2.3 \pm 0.8$ & $-1+$ & + \\
\hline tnd1 (4) & $0.01 \%$ AED & $2.9 \pm 0.5$ & $2.0 \pm 0.7$ & $-1+$ & + \\
\hline tnd2 (3) & $0.1 \%$ AED & n.d. & n.d. & $-1-$ & - \\
\hline$w t(10)$ & caffeine $e^{\ominus}$ & $2.7 \pm 1.0$ & $1.8 \pm 0.8$ & $+/+$ & + \\
\hline tnd1 (5) & caffeine $e^{\otimes}$ & $2.8 \pm 0.9$ & $1.8 \pm 0.5$ & $-1+$ & + \\
\hline tnd2 (6) & caffeine $^{e}$ & n.d. & n.d. & $-1-$ & - \\
\hline
\end{tabular}

${ }^{a}$ Cells injected with $100 \mu \mathrm{M}$ Fluo-3 and analysed, in presence of $\left[\mathrm{Ca}^{2+}\right]_{e}=50 \mu \mathrm{M}$ and $\mathrm{F}_{2} \mathrm{FITC}$ (to monitor membrane fusion), by CLSM for $\mathrm{f} / \mathrm{f}_{\mathrm{o}}$

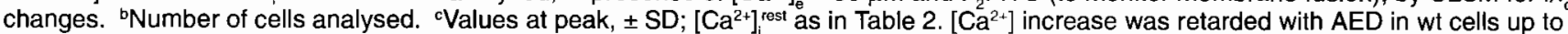
$10 \mathrm{~s}$, while maximum was achieved in $\leq 3 \mathrm{~s}$ in any other case. ${ }^{\mathrm{a}} \mathrm{F}_{2} \mathrm{FITC}$ binding was used to monitor membrane fusion even in absence of trichocyst decondensation. ${ }^{\circ} 40 \mathrm{mM}$ caffeine applied in all cases.

conditions, including protease inhibitors in isolation media, silver staining of gels, and ${ }^{45} \mathrm{Ca}$ overlays, were as indicated previously [47]. Briefly, for ${ }^{45} \mathrm{Ca}^{2+}$ binding assays, NC-membranes containing electrophoretically transferred trichocyst proteins from SDS-PAGE were soaked 3 times in IKM buffer $(10 \mathrm{mM}$ imidazole- $\mathrm{HCl}, 60$ $\mathrm{mM} \mathrm{KCl}, 5 \mathrm{mM} \mathrm{MgCl}_{2}$, and $0.5 \mathrm{mM}$ DTT, $\mathrm{pH} \mathrm{6.8)} \mathrm{at} 20^{\circ} \mathrm{C}$ for $30 \mathrm{~min}$, with three changes of the solution. After washing with IKM buffer, membranes were incubated with $50 \mathrm{ml}$ IKM buffer containing ${ }^{45} \mathrm{Ca}(17.7 \mu \mathrm{M}, 0.1-0.2$ $\mathrm{MBq} / \mathrm{ml}$ ) for $20 \mathrm{~min}$ at $20^{\circ} \mathrm{C}$. Unbound ${ }^{45} \mathrm{Ca}$ was removed by two washes, $2 \mathrm{~min}$ each, with $5 \% \mathrm{v} / \mathrm{v}$ ethanol. Membranes were then dried between filter paper and exposed to Kodak X-Omat film for $10-20$ days at $-70^{\circ} \mathrm{C}$ in Kodak X-Omatic cassettes with an intensifier screen [47].

\section{RESULTS}

\section{$\left[\mathrm{Ca}^{2+}\right]_{l}$ measurements}

Figure 1 shows a cortical $\left[\mathrm{Ca}^{2+}\right]_{\mathrm{i}}$ transient at the site of AED $(0.1 \%)$ application, paralleled by local trichocyst exocytosis. In the unstimulated cell, trichocysts occur in the condensed state as a corona of $\sim 10 \mu \mathrm{m}$ long rods in the cortex. (This is twice the length they have in $P$. tetraurelia [20].) Dislocation and deformation of a cell during vigorous trichocyst expulsion as long needles (opposite to curved, short cilia) is seen at $1.5 \mathrm{~s}$. Therefore, CISM $f / f_{o}$ analysis with high temporal resolution has been carried out. Figure 2 is a similar situation with local application of $40 \mathrm{mM}$ caffeine.

Figures 3 and 4 are analogous situations obtained with tnd 1 and AED or caffeine, respectively. In this case the $\left[\mathrm{Ca}^{2+}\right]_{\mathrm{i}}$ transients are even more pronounced than in wt cells, and spillover into the central region is also much
Table 2 Absolute $\left[\mathrm{Ca}^{2+}\right]_{i}$ values in P. caudatum

\begin{tabular}{|c|c|c|c|}
\hline Strain & $\begin{array}{l}{\left[\mathrm{Ca}^{2+}\right]_{i}^{\text {rest }}} \\
(\mathrm{nM})\end{array}$ & Secretagogue & $\begin{array}{l}{\left[\mathrm{Ca}^{2+}\right]_{i}^{\max }} \\
(\mathrm{nM})\end{array}$ \\
\hline \multirow[t]{3}{*}{ wt } & $112 \pm 45(8)$ & $0.01 \%$ AED & $\sim 110$ (unchanged) \\
\hline & & $0.1 \%$ AED & $325 \pm 90(6)$ \\
\hline & & $40 \mathrm{mM}$ caffeine & $302 \pm 112(10)$ \\
\hline \multirow[t]{3}{*}{ tnd1 } & $113 \pm 28(4)$ & $0.01 \%$ AED & $328 \pm 56(4)$ \\
\hline & & $0.1 \%$ AED & $294 \pm 90(4)$ \\
\hline & & $40 \mathrm{mM}$ caffeine & $316 \pm 102(5)$ \\
\hline
\end{tabular}

Determinations by Fura-Red double wavelength recordings and extrapolations from Fluo- $3 \mathrm{f} / \mathrm{f}_{0}$ measurements. $\left[\mathrm{Ca}^{2+}\right]_{\mathrm{e}}=50 \mu \mathrm{M}$. $\left[\mathrm{Ca}^{2+}\right]_{i}^{\max }$ indicates maximal increase in cell cortex during stimulation. $(n)=$ number of cells analysed, \pm SD.

stronger. Nevertheless, no trichocysts are released. Since in wt cells of $P$. caudatum any remarkable reaction occurred only with [AED] 10-fold in excess of $\mathrm{EC}_{100}$ in $P$. tetraurelia, $0.1 \%$ AED was applied also to tnd 1 cells (Table 1 ).

In Figures 1-4, Fluo-3 images reveal red spots originating from sequestered fluorochrome. These spots do not change during analysis and were excluded from quantitation. Based on a calibration scale $[17,18], f / f$ ratios were used to evaluate time-dependent $\left[\mathrm{Ca}^{2+}\right]$ transients in Figure 5. This ratio refers any actual value to that at $t_{0}$. Evaluation was done for areas framed in Figures 1-4, including the cortical stimulation area and a central region (selected in the center of the cell curvature). Pooled data are contained in Table 1.

Table 2 contains values of $\left[\mathrm{Ca}^{2+}\right]_{\mathrm{i}}$ in wt and tnd 1 cells at rest and cortical peak values during $A E D$ or caffeine stimulation. These have been calculated from $\left[\mathrm{Ca}^{2+}\right]_{i}^{\text {rest }}$ and $f / f_{o}$ values, based on a linear relationship (tested separately). Occasional direct measurements with tnd1, 
A

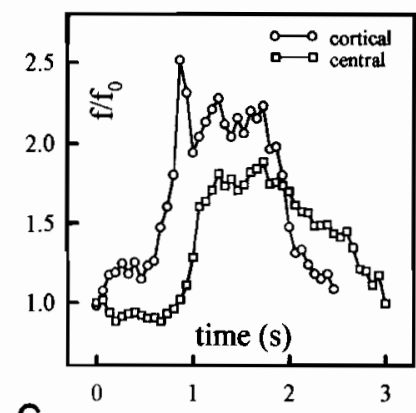

C

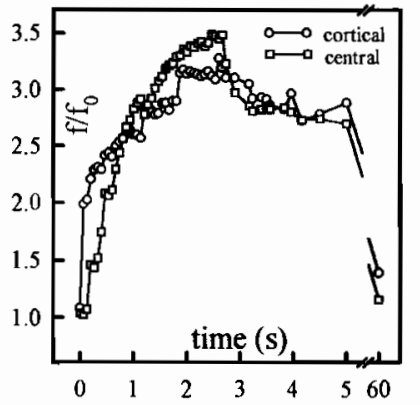

\section{B}
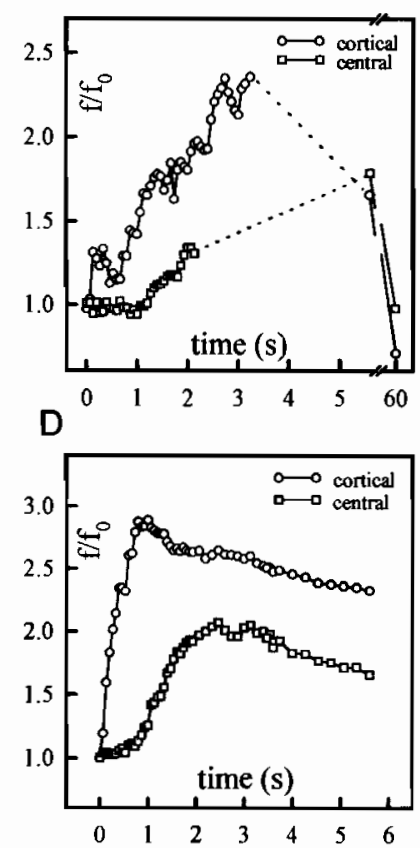

Fig. 5 Quantitative analysis of $\left[\mathrm{Ca}^{2+}\right]_{\text {, }}$ transients as $\mathrm{t} / \mathrm{f}_{\circ}$ ratio in areas shown in Figures 1-4, i.e. (A) after AED or (B) caffeine application to a wt cell, and (C) after AED or (D) caffeine application to a tnd1 cell.

Fura-Red and caffeine application yielded $\left[\mathrm{Ca}^{2+}\right]_{i}^{\text {act }}=320$ $\mathrm{nM}$, as compared to an average of $316 \mathrm{nM}$ determined by the indirect method. Remarkably $\left[\mathrm{Ca}^{2+}\right]_{i}^{\text {rest }}$ is about twice that in $P$. tetraurelia wt and nd $9\left(28^{\circ} \mathrm{C}\right)$ cells $[15,18]$, (see Discussion).

According to Figure 5 and Tables 1 and 2, caffeine in tnd 1 cells induces a $\left[\mathrm{Ca}^{2+}\right]_{\mathrm{i}}$ increase as potently as $0.1 \%$ AED, and tnd 1 cells react more rapidly and more strongly, even with $0.01 \%$ AED, than wt cells which require $0.1 \%$ AED for a similar $\left[\mathrm{Ca}^{2+}\right]_{\mathrm{i}}$ transient.

\section{Membrane fusion without contents' release}

This is documented in Figure 6, where a tnd 1 cell has been triggered with AED, supplemented with the exogenous fluorochrome, F FITC, for CLSM analysis. As we found, $F_{2}$ FITC can bind to decondensed (not shown) and condensed secretory materials of trichocysts. Binding occurs only once membrane fusion has occurred, thus allowing free access of the inert fluorochrome, $F_{2}$ FITC, from the medium. Over longer times condensed trichocysts stuck in an exocytotic opening may be lost, although normal extrusion by decondensation has never been observed. (Trichocysts from tnd 1 may decondense only by mechanical impairment, e.g. during vigorous homogenization [not shown].) For any time period, such

Table 3 Exocytotic response of $P$. caudatum wt and tnd 1 cells to variable concentrations of AED and extracellular $\mathrm{Ca}^{2+}$. Cells tested in suspension

\begin{tabular}{|c|c|c|c|c|}
\hline \multirow[t]{2}{*}{ Strain } & \multirow{2}{*}{$\begin{array}{l}{\left[\mathrm{Ca}^{2+}\right]_{e}} \\
(\mathrm{mM})\end{array}$} & \multirow{2}{*}{$\begin{array}{l}{[\mathrm{AED}]} \\
\%^{\mathrm{a}}\end{array}$} & \multicolumn{2}{|c|}{ Exocytotic response } \\
\hline & & & Discharge $^{b}$ & $\begin{array}{l}\text { Membrane } \\
\text { fusion }^{c}\end{array}$ \\
\hline$w t$ & 0.05 & 0.01 & ++ & + \\
\hline tnd1 & 0.05 & 0.01 & - & + \\
\hline$w t$ & 1.00 & 0.01 & ++ & + \\
\hline tnd1 & 1.00 & 0.01 & - & + \\
\hline$w t$ & 10.0 & 0.01 & ++ & + \\
\hline tnd1 & 10.0 & 0.01 & - & + \\
\hline$w t$ & 0.05 & 0.10 & +++ & + \\
\hline tnd1 & 0.05 & 0.10 & - & + \\
\hline wt & 1.00 & 0.10 & +++ & + \\
\hline tnd1 & 1.00 & 0.10 & - & + \\
\hline wt & 10.0 & 0.10 & +++ & + \\
\hline tnd 1 & 10.0 & 0.10 & - & + \\
\hline
\end{tabular}

${ }^{\mathrm{a}} 0.01 \%=2 \mu \mathrm{M}, 40 \mathrm{kDa}, 1-\mathrm{NH}_{2}$ group $/ \mathrm{kDa}$.

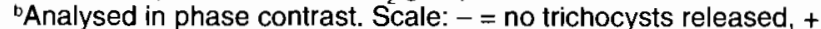
$=\leq 33 \%$. $++=>33 \%, \leq 66 \%,+++=>66 \%$ to $100 \%$ of trichocysts released. $100 \%$ release was ascertained by residual increase of $\leq$ $5 \%$ by picric acid (a fixative causing decondensation of all docked trichocysts).

'Registered by $\mathrm{F}_{2}$ FITC binding in tnd 1 cells; + indicates positive reaçtion.

cells remained fully viable. The same holds for tnd 1 cells after caffeine triggering (caffeine was washed out after stimulation). The 'grazing' focal plane in Figure 7 shows $\mathrm{F}_{2}$ FTTC tagged trichocyst tips stuck in exocytotic openings. These are characteristically located at 'perpendicular ridges' of depressed surface fields which themselves are recognized by $F_{2}$ FITC adsorption from the medium. Two different tnd 1 clones yielded essentially identical results.

As a control, we have included tnd 2 cells in Table 1. These are truly non-discharge, in the sense that they have no 'rosette' particles at trichocyst docking sites and no membrane fusion capacity $[45,46]$. As to be expected, tnd 2 cells do not perform membrane fusion in response to AED or caffeine, respectively, when analysed under the same conditions as tnd 1 cells.

Since decondensation of trichocyst contents during discharge depends on $\left[\mathrm{Ca}^{2+}\right]_{\text {e }}$ (see Introduction), this was increased from normally $50 \mu \mathrm{M}$ to $10 \mathrm{mM}$, but this did not increase trichocyst release from tnd 1 cells (Table 3 ). Since we generally experience that secretagogues induce exocytosis more efficiently when applied to cell suspensions, we also checked this aspect (Table 3). Stimulation effect was always controlled, e.g. in Table 3, by monitoring residual trichocyst release by adding the fixative, picric acid. Results with tnd 1 cells were all to the negative. 

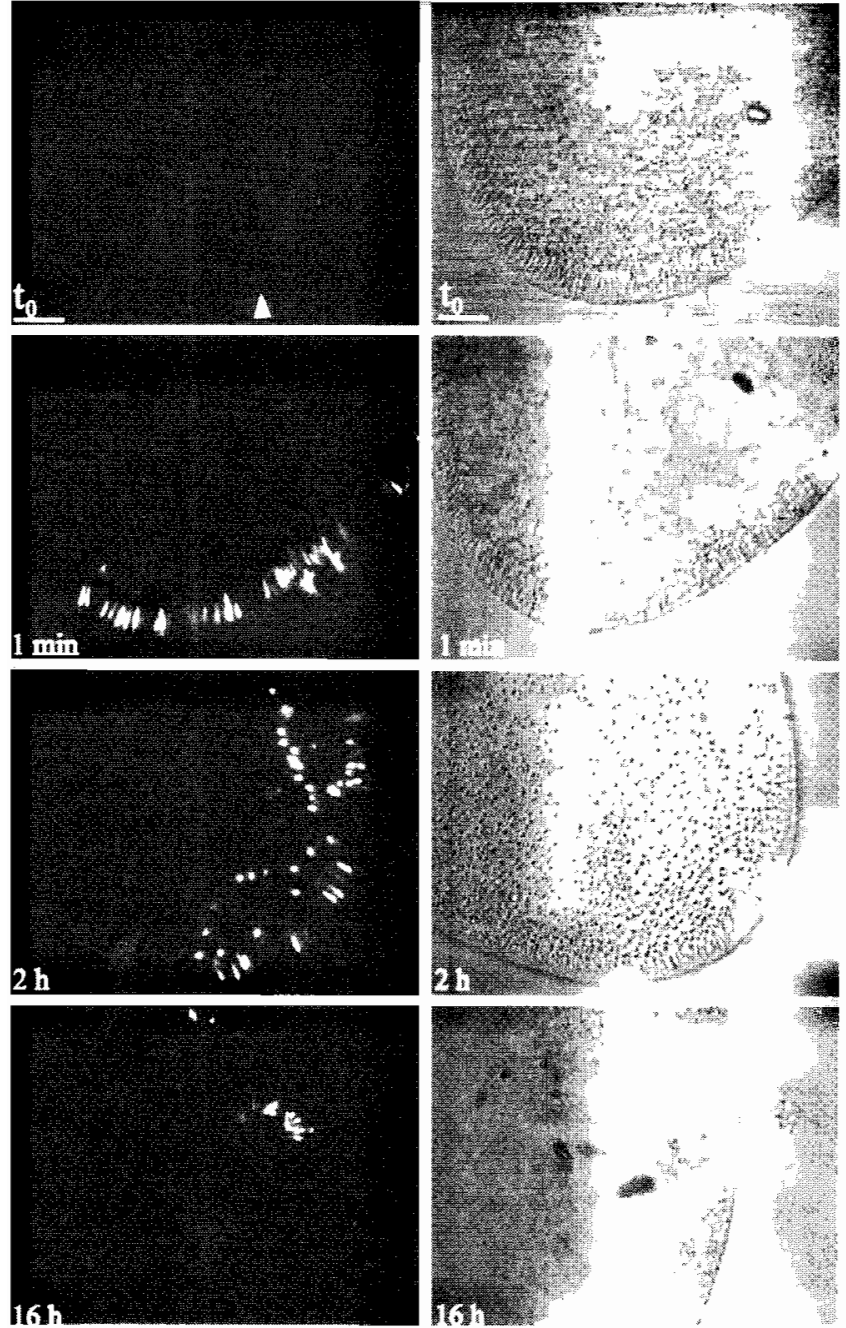

Fig. $6 \mathrm{~A}$ thd 1 cell has been locally triggered (arrowhead) at its anterior pole, in the presence of $\left[\mathrm{Ca}^{2+}\right]=50 \mu \mathrm{M}$, by $0.01 \% \mathrm{AED}$, supplemented with $10 \mu \mathrm{M} \mathrm{F}$ FITC for fluorescent labelling of trichocysts whose membranes have fused in the absence of contents discharge. Left row: fluorescence., Right row: DIC images, both in CLSM in a median plane. Note long-time retention of trichocysts with fused membranes in the cell. Bars $=10 \mu \mathrm{m}$.

\section{Spontaneous $\left[\mathrm{Ca}^{2+}\right]_{1}$ transients and spontaneous membrane fusions in tnd 1 cells}

So far, spontaneous $\left[\mathrm{Ca}^{2+}\right.$, increase could be observed only with tnd 1 cells from $P$. caudatum, but never with its wt counterpart or with any $P$. tetraurelia strain. An example is presented in Figure 8 showing spontaneous $\mathrm{f} / \mathrm{f}_{\mathrm{o}}$ increase, though with smaller amplitude than during stimulation, and the occurrence of $\mathrm{F}_{2}$ FITC binding without stimulation, all in a tnd1 cell. Unstimulated membrane fusion without trichocyst release is also seen on electron micrographs (Fig. 9). These also document
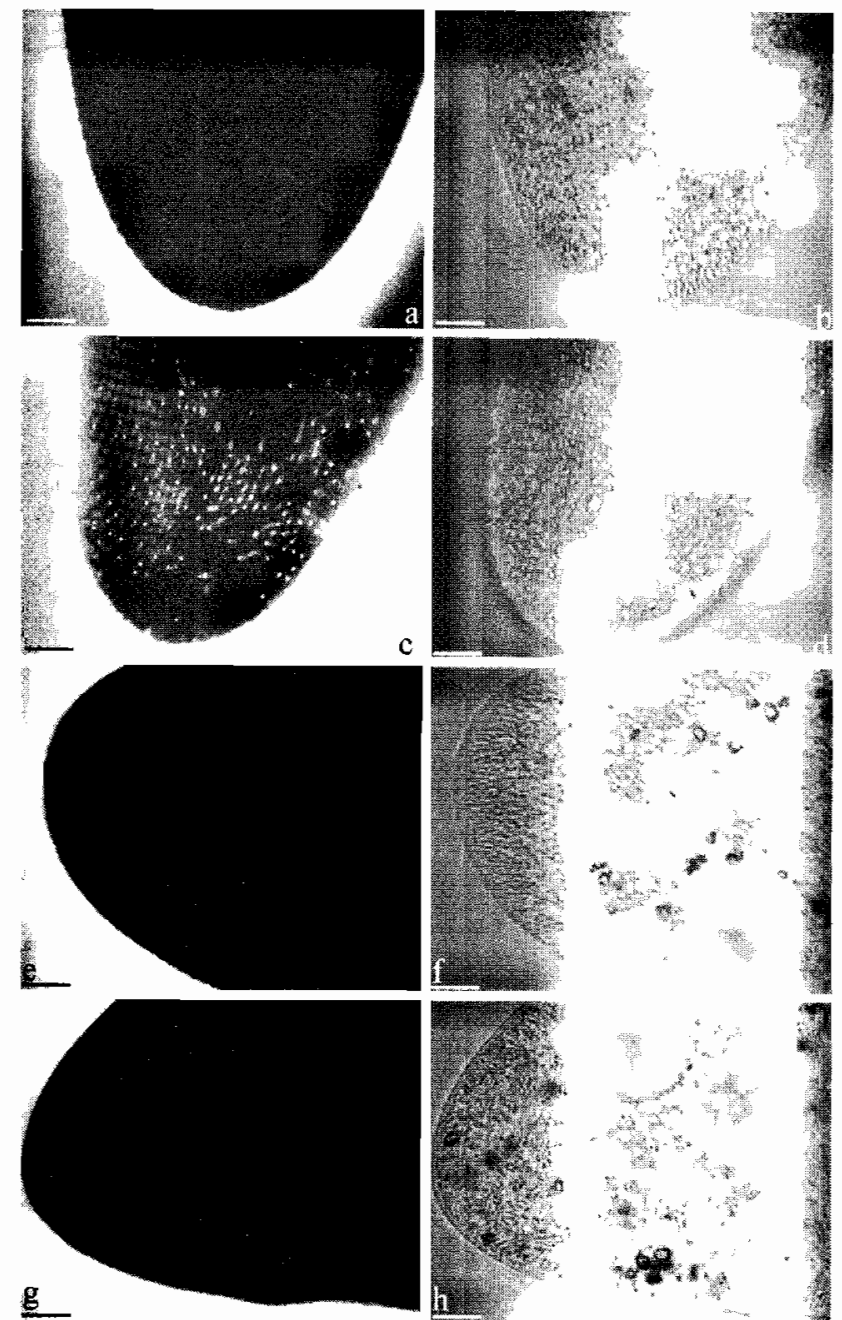

$\underline{\mathrm{g}}$
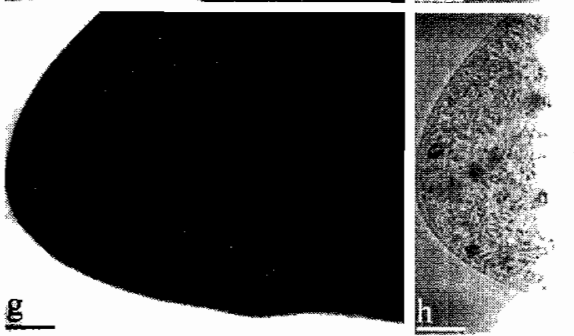

Fig. 7 (a-d) tnd1 versus ( $\mathbf{e}-\mathbf{h})$ wildtype cell. (a-d) Same situation as in Figure 6 , but tnd 1 cell (analysed by CLSM in a superficia plane) triggered by $40 \mathrm{mM}$ caffeine, also in presence of $10 \mu \mathrm{M}$ $F_{2}$ FITC. Untriggered control in fluorescence (a) and phase contrast (b), and similarly in (c,d) cell after stimulation. In (c) about $1 \times 1 \mu \mathrm{m}$ large fluorescent fields (representing the 'valleys' of surface fields characteristic of Paramecium cells) are visible, while bright dots at perpendicular ridges between these fields are trichocyst contents retained after membrane fusion, notably tips stuck in exocytotic openings. $(\mathbf{e}-\mathbf{h})$ The same arrangement with wildtype cells shows no retention of condensed trichocyst contents after stimulation and hence no fluorescence labelling. Bars $=10 \mu \mathrm{m}$.

presence of 'rosettes' (Fig. 9D), in agreement with previous work on tnd1 [46], occurrence of perfect membrane fusion (Fig. 9C,E), as well as a normal period (c.f. $[20,48]$ ) of the paracrystalline matrix (Fig. 9B). For comparison, the wildtype situation is precisely as shown in Figure 9A, with a normal trichocyst docking site (encircled area in an ultrathin section) and in Figure 9D, with a fusogenic docking site displaying a normal 'rosette' (in a freeze-fracture replica). Hence, non-discharge, in the 

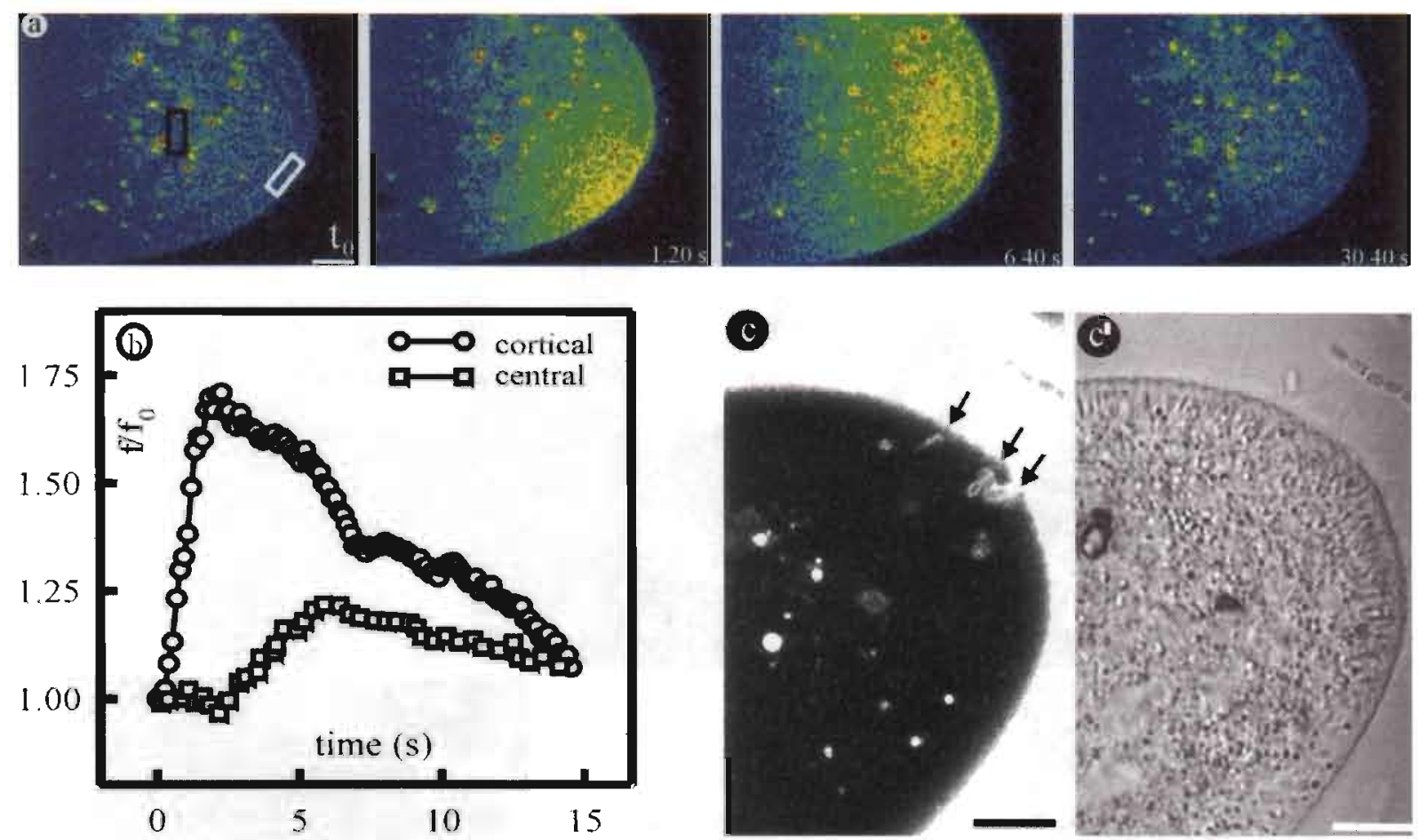

Fig. 8 Spontaneous cortical $\left[\mathrm{Ca}^{2+}\right]_{i}$ increase in a tnd 1 cell shown by Fluo $-3 \mathrm{f} / \mathrm{f}_{0}$ ratio imaging (a), with frames evaluated in (b), while (c) shows occurrence of untriggered membrane fusion without contents discharge (shown by exogenously added $F_{2}$ FITC). Fluo- 3 was injected several minutes before a spontaneous reaction started at $t_{0}$. Untriggered $\left[\mathrm{Ca}^{2+}\right]_{i}$ increase was observed by chance at the anterior pole of this cell. Arrows point to spontaneous reaction site. Bars $=10 \mu \mathrm{m}$.

context of tnd1, means inability to decondense trichocysts despite the occurrence of normal membrane fusion.

\section{Experiments with isolated trichocysts, SDS-PAGE and ${ }^{45} \mathrm{Ca}$ overlays}

The latter postulate was substantiated by exposing trichocysts, isolated with their membranes, to the $\mathrm{Ca}^{2+}$ ionophore, A23187. Whereas wt trichocysts could be readily stretched to needles, as occurring in vivo during exocytosis, no such reaction could be induced with tnd 1 trichocysts, even with rather high $\left[\mathrm{Ca}^{2+}\right]$ added (Fig. 10).

The question then arose whether tnd 1 trichocysts contain a regular set of 'trichynins' (see Introduction and Discussion). As in P. tetraurelia, these occur as a cluster of bands in SDS-PAGE the majority of which can be converted from higher apparent molecular weight (MW) to about half MW of $\sim 15-20 \mathrm{kDa}$ under reducing conditions [36-40,49]. Figure 11 shows such typical 'trichynin' bands (labeled by an asterisk) in trichocysts isolated from wt and tnd 1 cells. Both strains display bands of $15.1,15.4,15.8,16.8,17.6,18.4,18.8$, and 19.5 $\mathrm{kDa}$ under reducing conditions, as summarized in Table 4. These bands are much weaker under non-reducing conditions, when bands, e.g. of $\sim 29,30,31,32,34$ and 38
$\mathrm{kDa}$ are more abundant (not shown). This indicates monomer/dimer transition characteristic of trichynins [49]. Under reducing conditions, equivalents of $\sim 45$, $49-52$ and $\sim 65 \mathrm{kDa}$ bands known from $P$. tetraurelia [23] are also present in both $P$. caudatum strains. This, together with some still larger bands, might be attributed less to trichocyst membranes [50], but more likely to some non-trichynin type secretory components [51].

Despite some similarities in secretory contents, the two $P$. caudatum strains analysed greatly differed in the abundance of $16-19 \mathrm{kDa}$ as well as of the bands of $\geq 45$ $\mathrm{kDa}$. In the wt, low MW bands were abundant, while 45 , 49 and $\geq 75 \mathrm{kDa}$ bands were more abundant in tnd 1 . This indicates incomplete post-translational cleavage in the mutant, just as described on the basis of Western blot analysis [52-54]. Most importantly, some of the secretory contents proteins were now shown for the first time to co-incide with ${ }^{45} \mathrm{Ca}$ binding bands (Fig. 11), their MWs being specified in Table 4 . While the wt displays a large collection of varying intensity, the number of bands in tnd1 secretory contents is restricted to bands of moderate $(16,17 \mathrm{kDa})$ or spurious intensity $(19,26 \mathrm{kDa})$. Note that equal amounts of protein were applied to lanes in Figure 11. Imperfect cleavage can be only one reason of reduced ${ }^{45} \mathrm{Ca}$ binding, since the $45 \mathrm{kDa}$ band binds no 


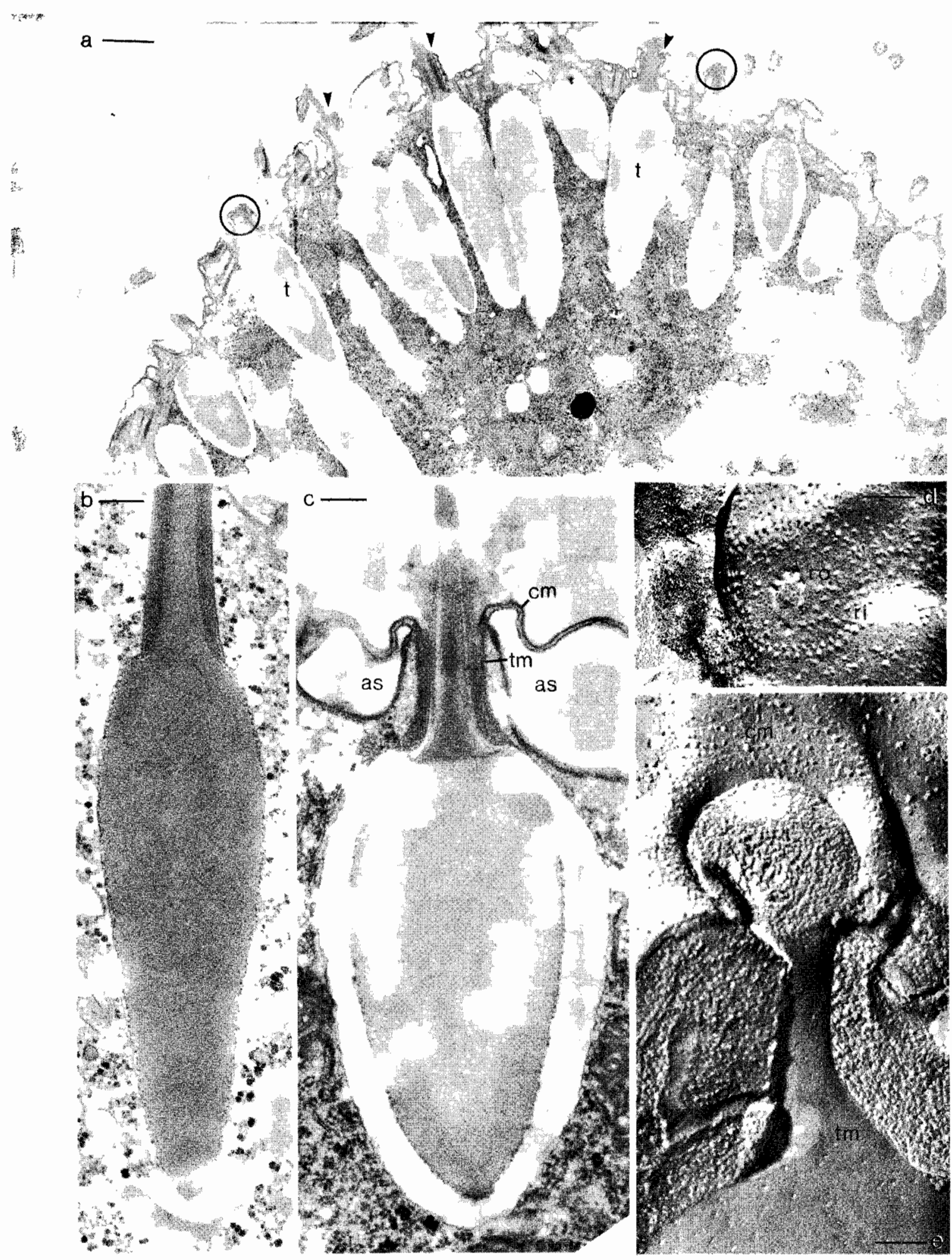

Fig. 9 EM analysis of trichocyst (t) docking sites in untriggered tnd1 cells by ultrathin sectioning $(a-c)$ and freeze-fracturing (d,e). Occurrence of spontaneous exocytotic membrane fusion is shown in (a) at arrowheads, as well as in (c) and in (e) which also allow to recognize perfect transition of the cell membrane $(\mathrm{cm})$ to the trichcoyst membrane $(\mathrm{tm})$. (b) Shows paracrystalline arrangement of trichocyst contents (matrix) with normal periodicity (despite incapability of decondensation), while (d) shows occurrence of particle 'ring' (ri) and 'rosette' (ro) (characteristic of fusion-competence). Several details are not different from the wildtype situation, for instance normal trichocyst docking sites on ultrathin sections (encircled in [a]) and occurrence of a rosette on freeze-fracture replicas (in [d]). as = alveolar sacs (subplasmalemmal calcium stores). Bars $=1 \mu \mathrm{m}(\mathbf{a}), 0.2 \mu \mathrm{m}(\mathbf{b}, \mathbf{c}), 0.1 \mu \mathrm{m}(\mathbf{d}, \mathbf{e})$. 

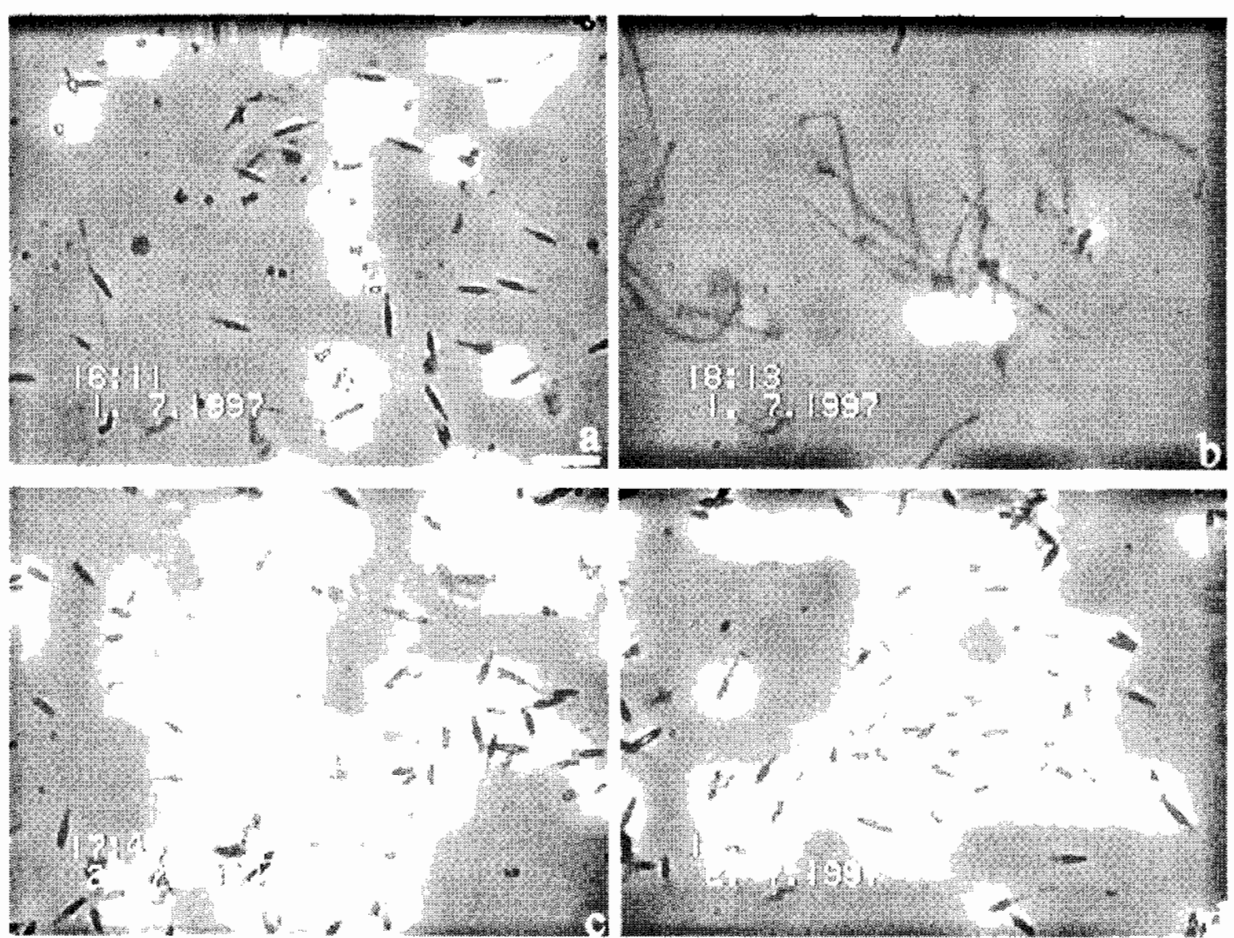

Fig. 10 Trichocysts isolated with their membranes $(a, b)$ from wt or $(c, d)$ from tnd1 cells, contained in a medium with $2.5 \mathrm{mM} \mathrm{Mg}^{2+}$ and 10 $\mathrm{mM} \mathrm{Ca}{ }^{2+}$, both as chlorides, pH 7.0. Samples in (b) and (d) were exposed to $100 \mu \mathrm{M} \mathrm{A23187}$ before $\mathrm{Ca}^{2-}$ was added. Note Ca ${ }^{2+}$-induced decondensation of wt (b), but not of tnd1 trichocysts (d). Bars $=10 \mu \mathrm{m}$.

Fig. 11 SDS-PAGE (+DTT) from trichocyst fractions isolated with their membranes from tnd1 (lanes 1,3) or wt (lines 2, 4) cells. Lanes 1,2 = silver staining, lanes $3,4={ }^{45} \mathrm{Ca}$ overlays. Note in lanes 1, 2 'trichynin' bands of 15-19 kDa (labeled by asterisk) which, together with some additional bands, occur in both strains in different intensity. Note occurrence of several intense ${ }^{45} \mathrm{Ca}$ binding bands in wt (lane 4), but their absence or weak labelling in tnd 1 (lane 3).

${ }^{45} \mathrm{Ca}$ in tnd 1 in contrast to the wt, while abundance of this protein is to the opposite. Both, reduced cleavage and ${ }^{45} \mathrm{Ca}$ binding are most likely the result from aberrant amino acid sequence, just as recently postulated $[55,56]$.

\section{DIscussion}

\section{$\left[\mathrm{Ca}^{2+}\right]_{\mathrm{i}}$ transients and exocytosis induction}

In $P$. caudatum wt cells, AED or caffeine induce some trichocyst exocytosis. However, for maximal response, AED concentrations had to be increased about 10 -fold (to $10 \mu \mathrm{M}$ ) over those required with $P$. tetraurelia wt cells [14]. Normally mobilisation from subplasmalemmal $\mathrm{Ca}^{2+}$ pools (alveolar sacs) and $\mathrm{Ca}^{2+}$ influx cooperate during AED [16-18,57-59] or caffeine stimulation [15]. Interestingly, basal $\left[\mathrm{Ca}^{2+}\right]_{i}$ values in $P$. caudatum cells are slightly different in $P$. tetraurelia, i.e. $110 \mathrm{nM}$ (Table 2) versus $\sim 50-70 \mathrm{nM}[18]$, but this difference has not been analysed in more detail. From this one cannot derive

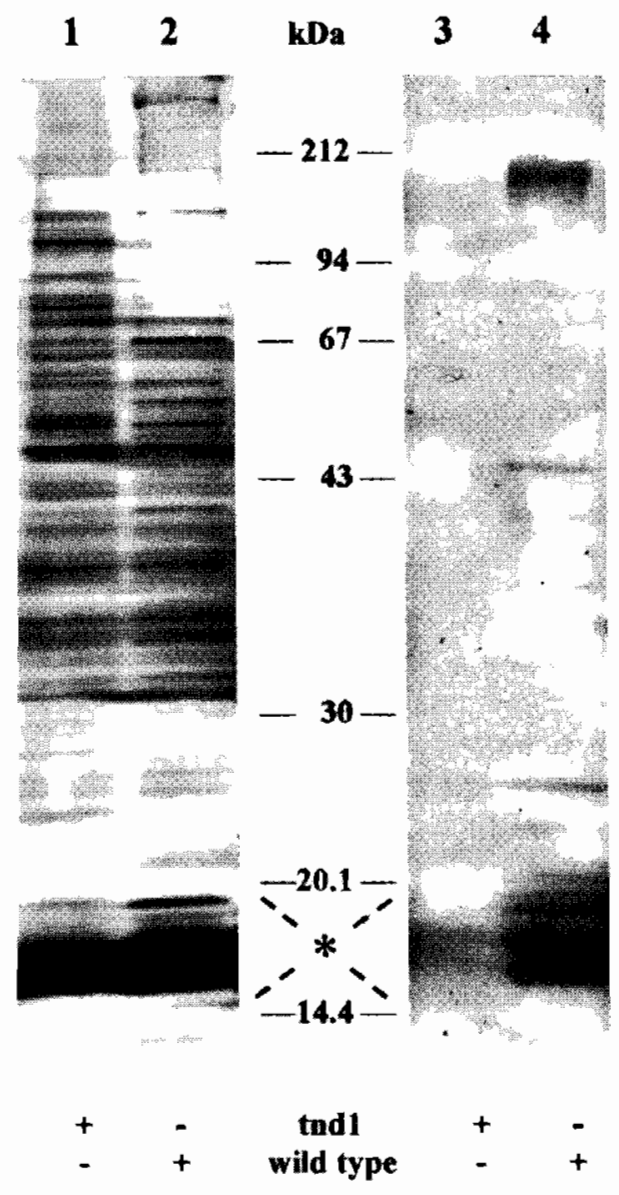


Table 4 Secretory proteins (silver stained) including Ca-binding proteins $\left({ }^{45} \mathrm{Ca}\right.$ overlays) in trichocysts isolated from $P$. caudatum tnd 1 and wt cells

\begin{tabular}{|c|c|c|c|c|}
\hline \multirow[t]{2}{*}{$\mathrm{kDa}$} & \multicolumn{2}{|c|}{ Silver staining } & \multicolumn{2}{|c|}{${ }^{45} \mathrm{Ca}$ binding } \\
\hline & tnd1 & wt & tnd1 & wt \\
\hline $165-190$ & - & - & - & +++++ \\
\hline 155 & - & - & - & ++ \\
\hline 141 & ++ & - & - & + \\
\hline 106 & +++ & + & - & - \\
\hline 90 & ++ & - & - & - \\
\hline 75 & ++ & + & - & - \\
\hline 65 & + & +++ & - & - \\
\hline 52 & - & ++ & - & - \\
\hline 49 & +++ & + & - & - \\
\hline 45 & +++++ & ++ & - & +++ \\
\hline 39 & - & - & - & ++ \\
\hline 35 & - & - & - & ++ \\
\hline 26 & - & - & $(+)$ & +++ \\
\hline 24 & - & - & - & ++ \\
\hline 20 & - & - & - & ++ \\
\hline 19 & ++ & +++++ & $(+)$ & ++++ \\
\hline $15-17$ & ++ & +++++ & ++ & +++++ \\
\hline
\end{tabular}

10-20\% SDS-PAGE + DTT. (+) to +++++ indicate band intensity, from spurious to most intense.

liability of tnd 1 cells to spontaneous $\left[\mathrm{Ca}^{2+}\right]_{\mathrm{i}}$ transients and membrane fusion, because $\left[\mathrm{Ca}^{2+}\right]_{\mathfrak{i}}^{\text {rest }}$ is quite similar to that in wt cells and because these are little sensitive to AED (see above). Since the increase in $\left[\mathrm{Ca}^{2+}\right]_{\mathrm{e}}$, which facilitates all exocytotic steps in $P$. tetraurelia [59] was without any effect on AED triggered exocytosis, the small $\left[\mathrm{Ca}^{2+}\right]_{\mathrm{i}}$ increase in $P$. caudatum wt cells might be due to less efficient store mobilisation. Regardless of the cause, spontaneous $\left[\mathrm{Ca}^{2+}\right]_{1}$ increases and membrane fusions clearly are co-incident events, implying a bypass of a step(s) normally controlling stimulated exocytosis.

\section{Lack of contents' decondensation in tnd1 cells}

This observation is without any precedent. Over 100 genes provide a family of closely related trichynins capable of self-assembly to a condensed paracrystalline body after proteolytic processing [52-54]. Contact with $\mathrm{Ca}^{2+}$ even at low concentrations (see Introduction), as occurring in the culture medium, normally causes rapid decondensation $[19,20,48]$, perhaps by a co-operative rearrangement of protein subunits. Abundant free negative charges of trichynins result from amino acid composition [49], while sulfation can be reasonably excluded [60]. Some of the trichynins could, therefore, bind $\mathrm{Ca}^{2+}$ during decondensation, and involvement of specific secretory $\mathrm{Ca}^{2+}$-binding proteins has been inferred from x-ray microanalysis [19] and recently, in Tetrahymena, from genetic analyses $[55,56]$. This is substantiated by our present finding of an abnormal set of trichynins in tnd 1 , undergoing only partial DTT-induced MW shift on SDSPAGE, and greatly reduced $\mathrm{Ca}^{2+}$-binding.

During AED stimulation, $\mathrm{Ca}^{2+}$ for trichocyst decondensation would have to come from the outside medium since mobilisation from internal sources in $P$. tetraurelia wt cells produces exocytotic openings with trichocysts retained in condensed form [22], just as we now find with $P$. caudatum strain tnd1. Even increasing $\left[\mathrm{Ca}^{2+}\right]_{\mathrm{e}}$ to 10 mM ( $100 \times$ above normal) did not cause decondensation of trichocysts in tnd 1 , while this greatly accelerates all steps of the exo-endocytotic cycle in $P$. tetraurelia wt cells [59]. Trichocysts from tnd 1 do not decondense even when exposed to $\mathrm{A} 23187+\mathrm{Ca}^{2+}$ (up to $50 \mathrm{mM}$ tested). Intracellular trichocyst decondensation, as sometimes observed with caffeine in $P$. tetraurelia nd $9\left(28^{\circ} \mathrm{C}\right)$ cells [15] also does not occur in tnd 1 cells. Therefore, we assume that tnd 1 trichocysts are unable to decondense in response to $\mathrm{Ca}^{2+}$, probably due to defective $\mathrm{Ca}^{2+}$ binding of some secretory components.

\section{Functional significance of trichocyst decondensation}

The rapid $\mathrm{Ca}^{2+}$-dependent decondensation mechanism may be prerequisite to the defensive function of trichocysts, as shown first by Harumoto and Miyake [61] and then in more detail by Knoll et al [62] and Miyake and Harumoto [63]. This may be valid only in the natural habitat, but hardly under laboratory conditions when triggered tnd 1 cells with numerous 'stuck' trichocysts maintain viability for many hours.

\section{ACKNOWLEDGEMENTS}

We thank Ms Claudia Braun, Sylvia Kolassa and Brunhilde Kottwitz for excellent technical assistance. This study has been supported by Deutsche Forschungsgemeinschaft grant P178/12 (to HP), and by the Ministry of Education, Science and Culture of Japan (to TW).

\section{REFERENCES}

1. Knoll G., Plattner H., Nordmann JJ. Exo-endocytosis in isolated peptidergic nerve terminals occurs in the sub-second range. Biosci Rep 1992; 12: 495-501.

2. Burgoyne R.D., Morgan A. Regulated exocytosis. Biochem J 1993; 293: 305-316.

3. von Gersdorff H., Matthews G. Dynamics of synaptic vesicle fusion and membrane retrieval in synaptic terminals. Nature 1994; 367: 735-739

4. von Gersdorff H., Matthews G. Inhibition of endocytosis by elevated internal calcium in a synaptic terminal. Nature 1994 ; 370: 652-655.

5. Rosenboom H., Lindau M. Exo- endocytosis and closing of the fission pore during endocytosis in single pituitary nerve 
terminals internally perfused with high calcium concentrations. Proc Natl Acad Sci USA 1994; 91: 5267-5271.

6. Thomas P., Lee A.K., Wong J.G., Almers W. A triggered mechanism retrieves membrane in seconds after $\mathrm{Ca}^{2+}$ stimulated exocytosis in single pituitary cells. J Cell Biol 1994; 124: $667-675$.

7. Rieke F., Schwartz E.A. Asynchronous transmitter release: control of exocytosis and endocytosis at the salamander rod synapse. J Physiol Lond 1996; 493: 1-8.

8. Smith C.B., Betz W.J. Simultaneous independent measurement of endocytosis and exocytosis. Nature 1996; 380: 531-534.

9. Wu L.G., Betz W.J. Nerve activity but not intracellular calcium determines the time course of endocytosis at the frog neuromuscular junction. Neuron 1996; 17: 769-779.

10. Zucker R.S. Exocytosis: a molecular and physiological perspective. Neuron 1996; 17: 1049-1055.

11. Plattner H., Lumpert C.J., Knoll G. et al. Stimulus-secretion coupling in Paramecium cells. Eur J Cell Biol 1991; 55: 3-16.

12. Plattner H., Knoll G., Erxleben C. The mechanics of biological membrane fusion. Merger of aspects from electron microscopy and patch-clamp analysis. J Cell Sci 1992; 103: 613-618.

13. Plattner H., Knoll G., Pape R. Synchronization of different steps of the secretory cycle in Paramecium tetraurelia: trichocyst exocytosis, exocytosis-coupled endocytosis and intracellular transport. In: Plattner H. (ed) Membrane Traffic in Protozoa. Greenwich, CT: JAI Press, 1993; 123-148.

14. Plattner H., Stürzl R., Matt H. Synchronous exocytosis in Paramecium cells. IV. Polyamino compounds as potent trigger agents for repeatable trigger-redocking cycles. Eur J Cell Biol 1985; 36: 32-37

15. Klauke N., Plattner $\mathrm{H}$. Caffeine-induced $\mathrm{Ca}^{2+}$ transients and exocytosis in Paramecium cells. A correlated $\mathrm{Ca}^{2+}$ imaging and quenched-flow/freeze-fracture analysis. J Membr Biol 1998; 158 197-208.

16. Erxleben C., Plattner $\mathrm{H} . \mathrm{Ca}^{2+}$ release from subplasmalemmal stores as a primary event during exocytosis in Paramecium cells. J Cell Biol 1994; 127: 935-945.

17. Erxleben C., Klauke N., Flötenmeyer M., Blanchard M.P., Braun C., Plattner $\mathrm{H}$. Microdomain $\mathrm{Ca}^{2+}$ activation during exocytosis in Paramecium cells. Superposition of local subplasmalemmal calcium store activation by local $\mathrm{Ca}^{2+}$ influx. J Cell Biol 1997; 136: 597-607.

18. Klauke N., Plattner H. Imaging of $\mathrm{Ca}^{2+}$ transients induced in Paramecium cells by a polyamine secretagogue. J Cell Sci 1997; 110: 975-983.

19. Bilinski M., Plattner H., Matt H. Secretory protein decondensation as a distinct $\mathrm{Ca}^{2+}$-mediated event during the final steps of exocytosis in Paramecium cells. J Cell Biol 1981; 88: $179-188$

20. Kersken $H$., Tiggemann R., Westphal C., Plattner $H$. The secretory contents of Paramecium tetraurelia trichocysts: ultrastructural-cytochemical characterization. $J$ Histochem Cytochem 1984; 32: 179-192.

21. Lima D., Gulik-Krzywicki T., Sperling L. Paramecium trichocysts isolated with their membranes are stable in the presence of millimolar $\mathrm{Ca}^{2+}$. J Cell Sci 1989; 93: 557-564.

22. Matt H., Plattner H. Decoupling of exocytotic membrane fusion from protein discharge in Paramecium cells. Cell Biol Int Rep 1983; 7: 1025-1031.

23. Glas-Albrecht R., Plattner H. High yield isolation procedure for intact secretory organelles (trichocysts) from different Paramecium tetraurelia strains. Eur J Cell Biol 1990; 53: 164-172.

24. Kerboeuf D., Cohen J. A Ca ${ }^{2+}$ influx associated with exocytosis is specifically abolished in a Paramecium exocytotic mutant. $J$ Cell Biol 1990; 111: 2527-2535.
25. Schmitz M., Meyer R., Zierold K. X-ray microanalysis in cryosections of natively frozen Paramecium caudatum with regard to ion distribution in ciliates. Scanning Electron Microsc $1985 ; 1: 433-445$.

26. Schmitz M., Zierold K. X-ray microanalysis of ion changes during fast processes of cells, as exemplified by trichocyst exocytosis of Paramecium caudatum. In: Plattner H. (ed) Electron Microscopy of Subcellular Dynamics. Boca Raton, FL: CRC Press, 1989; 325-339.

27. Zierold K., Gerke I., Schmitz M. X-ray microanalysis of fast exocytotic processes. In: Zierold K., Hagler H.K. (eds) Electron Probe Microanalysis. Berlin: Springer, 1989; 281-292

28. Winkler $\mathrm{H}$. The biogenesis of adrenal chromaffin granule. Neuroscience $1977 ; 2$ : 657-683.

29. Winkler $\mathrm{H}$. The adrenal chromaffin granule: a model for large dense core vesicles of endocrine and nervous tissue. $J$ Anat 1993; 183: 237-252.

30. Gerdes H.H., Rosa P., Phillips E. et al. The primary structure of human secretogranin II, a widespread tyrosine-sulfated secretory granule protein that exhibits low $\mathrm{pH}$ - and calciuminduced aggregation. J Biol Chem 1989; 264: 12009-12015.

31. Chanat E., Huttner W.B. Milieu-induced selective aggregation of regulated secretory proteins in the trans-Golgi network. $J$ Cell Biol 1991; 115: 1505-1519.

32. Nicaise G., Maggio K., Thirion S., Horoyan M., Keiche, E. The calcium loading of secretory granules. A possible key event in stimulus-secretion coupling. Biol Cell 1992; 75: 89-99.

33. Anderson R.G.W., Orci L. A view of acidic intracellular compartments. J Cell Biol 1988; 106: 539-543.

34. Lumpert C.J., Glas-Albrecht R., Eisenmann E., Plattner H. Secretory organelles of Paramecium cells (trichocysts) are not remarkably acidic compartments. J Histochem Cytochem 1992; 40: $153-160$

35. Garreau De Loubresse N., Gautier M.C., Sperling L. Immature secretory granules are not acidic in Paramecium: implications for sorting to the regulated pathway. Biol Cell 1995; 82: 139-147.

36. Adoutte A., Ramanathan R., Lewis R.M. et al. Biochemical studies of the excitable membrane of Paramecium tetraurelia. III. Proteins of cilia and ciliary membranes. J Cell Biol 1980; 84: 717-738.

37. Tindall S.H. Selection of chemical spacers to improve isoelectric focussing resolving power: implications for use in twodimensional electrophoresis. Anal Biochem 1986; 159: 287-294.

38. Tindall S.H., Devito L.D., Nelson D.L. Biochemical characterization of the proteins of Paramecium secretory granules. J Cell Sci 1989; 92: 441-447.

39. Pollack S. Mutations affecting the trichocysts in Paramecium aurelia. I. Morphology and description of the mutants. $J$ Protozool 1974; 21: 352-362.

40. Beisson J., Lefort-Tran M., Pouphile M., Rossignol M., Satir B. Genetic analysis of membrane differentiation in Paramecium. Freeze-fracture study of the trichocyst cycle in wild-type and mutant strains. J Cell Biol 1976; 69: 126-143.

41. Beisson J., Cohen J., Lefort-Tran M., Pouphile M., Rossignol M. Control of membrane fusion in exocytosis. Physiological studies on a Paramecium mutant blocked in the final step of the trichocyst extrusion process. J Cell Biol 1980; 85: 213-227.

42. Lefort-Tran M., Aufderheide K., Pouphile M., Rossignol M. Beisson J. Control of exocytotic processes: cytological and physiological studies of trichocyst mutants in Paramecium tetraurelia. J Cell Biol 1981; 88: 301-311.

43. Pouphile M., Lefort-Tran M., Plattner H., Rosignol M., Beisson J. Genetic dissection of the morphogenesis of exocytosis sites in Paramecium. Biol Cell 1986; 56: 151-162. 
44. Gautier M.C., Garreau De Loubresse N., Madeddu L., Sperling L. Evidence for defects in membrane traffic in Paramecium secretory mutants unable to produce functional storage granules. J Cell Biol 1994; 124: 893-902.

45. Takei K., Watanabe T., Hiwatashi K. Trichocyst nondischarge mutants in Paramecium caudatum. Zool Sci 1986; 3: 759-764.

46. Watanabe T., Haga N. Genetic characterization of the secretory mutants in Paramecium caudatum. Protoplasma 1996; 192: 11-19.

47. Kissmehl R., Treptau T., Kottwitz B., Plattner H. Occurrence of a para-nitrophenyl phosphate phosphatase with calcineurin characteristics in Paramecium tetraurelia. Arch Biochem Biophys 1997; 344: 260-270.

48. Sperling L., Tardieu A., Gulik-Krzywicki T. The crystal lattice of Paramecium trichocysts before and after exocytosis by $\mathbf{x}$-ray diffraction and freeze-fracture electron microscopy. J Cell Biol 1987; 105: 1649-1662.

49. Steers E., Beisson J., Marchesi V.T. A structural protein extracted from the trichocyst of Paramecium aurelia. Exp Cell Res 1969; 57: 392-396.

50. Glas-Albrecht R., Schlosser V., Plattner H. Isolation of the membranes from secretory organelles (trichocysts) of Paramecium tetraurelia. Biochim Biophys Acta 1992; 1103: 1-7.

51. Glas-Albrecht R., Németh A., Plattner H. Secretory proteins and glycoproteins from Paramecium cells. Eur J Protistol 1990; 26: 149-159.

52. Madeddu L., Gautier M.C., LeCaer J.P., Garreau De Loubresse N., Sperling L. Protein processing and morphogenesis of secretory granules in Paramecium. Biochimie 1994; 76: 329-335.

53. Madeddu L., Gautier M.C., Vayssié L., Houari A., Sperling L. A large multigene family codes for the polypeptides of the crystalline trichocyst matrix in Paramecium. Mol Biol Cell 1995; 6: 649-659.

54. Gautier M.C., Sperling L., Madeddu L. Cloning, sequence analysis of genes coding for Paramecium secretory granule (trichocyst) proteins. A unique protein fold for a family of polypeptides with different primary structures. J Biol Chem 1996; 271: 10247-10255.

55. Turkewitz A.P., Madeddu L., Kelly R.B. Maturation of dense core granules in wild type and mutant Tetrahymena thermophila. EMBO J 1991; 10: 1979-1987.

56. Chilcoat N.D., Melia S.M., Haddad A., Turkewitz A.P. Granule lattice protein 1 (Grl1p), an acidic, calcium-binding protein in Tetrahymena thermophila dense core secretory granules, influences granule size, shape, content organization, and release but not protein sorting or condension. J Cell Biol 1996. 135: 1775-1787.

57. Knoll G., Kerboeuf D., Plattner H. A rapid calcium influx during exocytosis in Paramecium cells is followed by a rise in cyclic GMP within 1 s. FEBS Lett 1992; 304: 265-268.

58. Knoll G., Grässle A., Braun C., Probst W., Höhne-Zell B., Plattner $\mathrm{H}$. A calcium influx is neither strictly associated with nor necessary for exocytotic membrane fusion in Paramecium cells. Cell Calcium 1993; 14: 173-183.

59. Plattner H., Braun C., Hentschel J. Facilitation of membrane fusion during exocytosis and exocytosis-coupled endocytosis and acceleration of 'ghost' detachment in Paramecium by extracellular calcium. A quenched-flow/freeze-fracture analysis. J Membr Biol 1997; 158: 197-208.

60. Huttner W.B., Baeuerle P.A. Protein sulfation on tyrosine. Mod Cell Biol 1988; 6: 97-140.

61. Harumoto T., Miyake A. Defensive function of trichocysts in b25 Paramecium. J Exp Zool 1991; 260: 84-92.

62. Knoll G., Haacke-Bell B., Plattner H. Local trichocyst exocytosis provides an efficient escape mechanism for Paramecium cells. Eur J Protistol 1991; 27: 381-385.

63. Miyake A., Harumoto T. Defensive function of trichocysts in Paramecium against the predatory ciliate Monodinium balbiani. Eur J Protistol 1996; 32: 128-133. 